378.013.3

\author{
ВЕРТИКАЛЬНА РЕДУКЦІЯ ЗМІСТУ НАВЧАННЯ ТЕМИ «СПОСТЕРЕЖЕННЯ ЗА \\ ВІДХОДАМИ» ДИСЦИПЛІНИ «МОНІТОРИНГ СЕРЕДОВИЩА ІСНУВАННЯ» \\ ОШматков Д. І. ${ }^{1}$, Бслікова Н. В ${ }^{2}$., Шелковий О. О. ${ }^{1}$ \\ Українська інженерно-педагогічна академія $^{l}$ \\ Науково-дослідний центр індустріальних проблем розвитку НАН Украӥни 2
}

Шматков Даніiл Ігорович: ORCID: 0000-0003-2952-4070 d.shmatkov@uipa.edu.ua; кандидат педагогічних наук, доцент кафедри охорони праці, стандартизації та сертифікації; Українська інженернопедагогічна академія; вул. Університетська, 16, м. Харків, 61003, Україна.

Бєлікова Надія Володимирівна. ORCID: 0000-0002-5082-2905 nadezdabelikova@gmail.com; доктор економічних наук, доцент, учений секретар, Науково-дослідний центр індустріальних проблем розвитку НАН України; пров. Інженерний, 1а, м. Харків, 61166, Україна

Шелковий Олександр Олександрович: ORCID: 0000-0002-8486-090X; shelkoviy.o@gmail.com; acпiрант кафедри фізики, електротехніки і електроенергетики; Українська інженерно-педагогічна академія; вул. Університетська, 16, м. Харків, 61003, Україна.

На підставі теоретичного аналізу науково-технічної та науково-методичної літератури, вивчення і узагальнення досвіду розробки методів дидактичної редукції, із застосуванням методів математичної статистики розроблено метод вертикальної дидактичної редукції змісту навчання у вищій школі моніторингу відходів середовища існування. Метод відповідає характерним ознакам дидактичної редукції - допомагає надати змісту певної форми і узгодити його із нормованим часом, а також забезпечує формування обсягу достатньої інформації для оволодіння конкретним аспектом моніторингу відходів середовища існування. При цьому достатність змісту обгрунтовано, перевірено та підтверджено методами математичної статистики, що дозволило трансформувати якісні змінні «достатньо» та «важливо» у кількісні змінні. Застосування методу призводить до зменшення часу на проведення вимірювань, розрахунків, аналізу за отримання наближеного результату при статистично малих похибках, що дозволяе максимізувати інформацію щодо отриманих результатів в умовах обмеженого часу на навчання моніторингу відходів середовища існування, а також в умовах обмеженого часу його безпосереднього здійснення у майбутній професійній діяльності.

Ключові слова: дидактична редукція, зміст навчання, моніторинг середовища існування, відходи, математична статистика, вимірювання, екологія, навчальний час.

Шматков Д. И. Беликова Н. В. Шелковый А. А. «Вертикальная редукция содержания обучения темы «Наблюдение за отходами» дисциплины «Мониторинг среды обитания»

На основании теоретического анализа научно-технической и научно-методической литературы, изучения и обобщения опыта разработки методов дидактической редукции, с применением методов математической статистики разработан метод вертикальной дидактической редукции содержания обучения в высшей школе мониторинга отходов среды обитания. Метод соответствует характерным признакам дидактической редукции - помогает придать содержанию определенную форму и согласовать его с нормированным временем, а также обеспечивает формирование объема достаточной информации для овладения конкретным аспектом мониторинга отходов среды обитания. При этом достаточность содержания обоснована, проверена и подтверждена методами математической статистики, что позволило трансформировать качественные переменные «достаточно» и «важно» в количественные переменные. Применение метода приводит к уменьшению времени на проведение измерений, расчетов, анализа при получении приближенного результата при статистически малых погрешностях, что позволяет максимизировать информацию о полученных результатах в условиях ограниченного времени на обучение мониторинга отходов среды обитания, а также в условиях ограниченного времени его непосредственного осуществления в будущей профессиональной деятельности.

Ключевые слова: дидактическая редукция, содержание обучения, мониторинг среды обитания, отходы, математическая статистика, измерения, экология, учебное время. 
D.Shmatkov, N. Bielikova, A. Shelkovyj "Vertical reduction of the learning content of the topic "Waste observation" of the discipline "Environmental monitoring"

After conducting a theoretical analysis of scientific, technical and methodological literature, studying and summarizing the experience of designing methods of didactic reduction, a method of vertical didactic reduction of the learning content of the environmental waste monitoring as an academic discipline has been developed using the methods of mathematical statistics. The method corresponds to the characteristic features of didactic reduction as it helps to transform the content into a certain form and coordinate it with the study time, and also ensures the formation of a certain amount of sufficient information to learn a specific aspect of the topic of the environmental waste monitoring. At the same time, the sufficiency of the content is substantiated, verified and confirmed using the methods of mathematical statistics, which made it possible to transform the qualitative variables "sufficiently" and "importantly" into quantitative variables. The implementation of the method leads to a decrease in time for measurements, calculations, and analysis when obtaining an approximate result with statistically small errors. It results in the maximization of information about the results obtained under conditions of limited study time, as well as under conditions of limited time for its implementation in future professional activities.

Keywords: didactic reduction, learning content, environmental monitoring, waste, mathematical statistics, measurements, ecology, study time.

Постановка проблеми. Зміст навчання моніторингу середовища існування у вищій школі поєднує в собі метрологічний та екологічні напрями. Це обумовлює перевантаження студентів змістом дисципліни, a також висуває вимоги до викладача 3 раціонального формування ii програми. Нормативні вимоги до часу, відведеного на навчання моніторингу середовища існування обмежують зміст, що може бути охоплений тими, хто навчається. Крім того, умови професійної діяльності також можуть накладати обмеження на час, що отримує професіонал в галузі на проведення відповідних заходів 3 моніторингу. У цьому контексті існує потреба у науково обгрунтованому методі зменшення інформації до такого об'єму, що буде відповідати умовам його застосування.

Аналіз останніх досліджень i публікацій. Підходи до формування змісту навчання моніторингу середовища існування варіюються. Так, у праці Г. Кіпоренко [1] розглянуто передумови створення системи моніторингу, моніторинг, як систему спостережень за впливом на середовище існування антропогенних чинників, рівні та види моніторингу довкілля, організацію та здійснення системи моніторингу довкілля в Україні та інших країнах. Ці аспекти можуть мати різний зміст у різноманітних методичних системах в залежності від стану розвитку науки, чинного законодавства або інших нормативних документів тощо. Крім того, у праці грунтовно аналізуються такі напрями, як моніторинг атмосферного повітря, моніторинг поверхневих вод, моніторинг світового океану, моніторинг радіоактивного забруднення природного середовища, принципи організації спостережень i контролю забруднюючих речовин грунтів.

У статистичному збірнику «Довкілля України» [2] напрями моніторингу представлено у більш широкому форматі. Так, зокрема передбачено проведення моніторингу атмосферного повітря, використання водних ресурсів, утворення відходів та поводження 3 ними, внесення добрив i застосування пестицидів, охорони та використання лісових ресурсів, оцінки витрат на охорону навколишнього природного середовища. Такі напрями моніторингу $\epsilon$ найпоширенішими $\mathrm{i}$ кожен 3 них включає певну кількість показників. Проте, в процесі навчання важко дотриматись повного відображення змісту предметної галузі. Виключення одного 3 напрямів викладачем в процесі навчання у вищій школі може призвести до епізодичного та нецілісного оволодіння студентами змістом дисципліни.

Відомими $є$ інноваційні підходи до навчання моніторингу середовища існування, представлені в патентній документації. Так, відомою є методика [3], що реалізується із застосуванням системи моніторингу, яка включає в себе, принаймні, один датчик для визначення ситуації в навколишньому середовищі та генерації за меншим рівнем даних моніторингу навколишнього середовища; сервер моніторингу для прийому, принаймні, одних даних моніторингу навколишнього середовища; проксі-сервер, електрично пов'язаний 3 сервером моніторингу та приймаючий, принаймні, одну інформацію моніторингу навколишнього середовища; множину користувацьких терміналів. Система 
моніторингу може отримувати, принаймні, одну інформацію моніторингу навколишнього середовища в режимі реального часу. Проте, у винаході не міститься опису специфіки моніторингу декількох параметрів навколишнього середовища, що обмежує його застосування у навчальному процесі за повного дотримання програми дисципліни.

Відомою також є корисна модель [4], яка забезпечує у навчальному процесі допомогу 3 класифікації відходів. Проте, технічне рішення обмежено лише класифікацією і не розкриває специфіки проведення різноманітних вимірювань у галузі. Питання моніторингу відходів та поводження 3 ними, як видно 3 попереднього аналізу, $€$ одним 3 найважливіших у процесі моніторингу середовища існування.

Представлені інноваційні технології стосуються здебільшого засобів навчання, їх застосування обмежено вузькими аспектами змісту навчання моніторингу середовища існування. Удосконалення змісту 3 метою найбільш раціонального його представлення та оволодіння повинно бути комплексним.

Створення науково обгрунтованих методів зниження когнітивної складності змісту навчання знаходиться в межах підходу, що в ЄС прийнято називати «дидактичною редукцією», в американській науковій літературі напрям є складовою «симпліфікації навчання».

Дидактична редукція ставить на меті ретельний відбір та переструктурування навчального матеріалу, а не нехтування важливою інформацією. Методи дидактичної редукції допомагають надати змісту певної форми і узгодити його із нормованим часом. Показовим прикладом дидактичної редукції у розробці навчального плану $\epsilon$ вивчення у школі лише обраних найвидатніших письменників або художників [5].

Відомим $є$ підхід до розробки редукованого змісту навчання біометрії та епідеміології [6]. Ці курси часто містять великий обсяг матеріалу, i, на думку авторів, викладаються за відсутності відповідних дидактичних методів зменшення змісту для цільової аудиторії. Загальна мета удосконалення полягає в поліпшенні довгострокової доступності знань 3 дисциплін. Впровадження певного ступеню стандартизації підходів до навчання із застосуванням дидактичної редукції призвело до успішності реалізації цього процесу та задоволеності студентів.
Відповідно до ідей засновника напряму, німецького вченого Г. Грюнера [7], дидактична редукція по відношенню до змісту навчання може нести вертикальний або горизонтальний характер. Не все, що має відношення до дисципліни, підлягає вивченню та запам'ятовуванню. Велика кількість інформації ускладнює когнітивні процеси. Деякі аспекти предметної галузі повинні бути опущені. Зменшення кількості інформації несе вертикальний характер редукції, а ілюстративне або символічне представлення інформації, застосування знайомих моделей та аналогій тощо, тобто зміна форми представлення інформації без зменшення іiі кількості несе горизонтальний характер редукції.

У той час, як пропонуються різноманітні методи та технології в межах горизонтального характеру дидактичної редукції [8, 9], наукове обгрунтування впровадження методів вертикальної редукції в літературі розглянуто обмежено. У цих працях запропоновано використання каузальних карт, що відображають зв'язки між фізичними основами вимірювання, схемами засобів вимірювання та методикою використання засобів вимірювання, у навчанні відповідних тем природничих, технічних, соціальних та гуманітарних наук; застосування теорії графів, спрямованих на розуміння логічної структури змісту навчання тощо. Наведені методи забезпечують опущення чинників, що не мають визначального впливу на ситуацію та абстрагування; отримання у вершинах графу понять меншого обсягу, ніж у навчальних текстах; ілюстративне або символічне представлення складної інформації; розгляд ситуацій на основі відомих моделей; зведення кількісних змінних у формулах до їх якісних пояснень та представлення відношення між ними. Процес вирішення завдань різного рівня складності із застосуванням методів та засобів дидактичної редукції дозволяє впливати на додаткові канали сприйняття, та, через, наприклад, розуміння студентами причиннонаслідкових зв’язків, дозволяє інтенсифікувати розвиток їх мислення та пам'яті.

Важливими є теоретичні дослідження Д. Бушфілда [10], який виокремлює поділ інформації на достатню і зайву, а також повну i неповну. За думкою автора дидактична редукція повинна стосуватись класифікації «достатня - зайва інформація».

Саме в контексті достатності інформації зміст навчання у вищій школі моніторингу 
ISSN 2074-8922 «Проблеми інженерно-педагогічної освіти», 2018, № 61

\section{3МICT ОСВITИ}

відходів середовища існування може бути редукований.

Постановка завдання. Завданням статті є розробка методу вертикальної редукції змісту навчання у вищій школі моніторингу середовища існування.

Виклад основного матеріалу. На підставі теоретичного аналізу науковотехнічної та науково-методичної літератури, вивчення i узагальнення досвіду розробки методів дидактичної редукції, представлених у попередньому розділі, із застосуванням методів математичної статистики розроблено метод вертикальної дидактичної редукції змісту навчання у вищій школі моніторингу відходів середовища існування, розділу, що є одним зі складових дисципліни.

Розглянемо розроблений метод (рис. 1) більш детально.

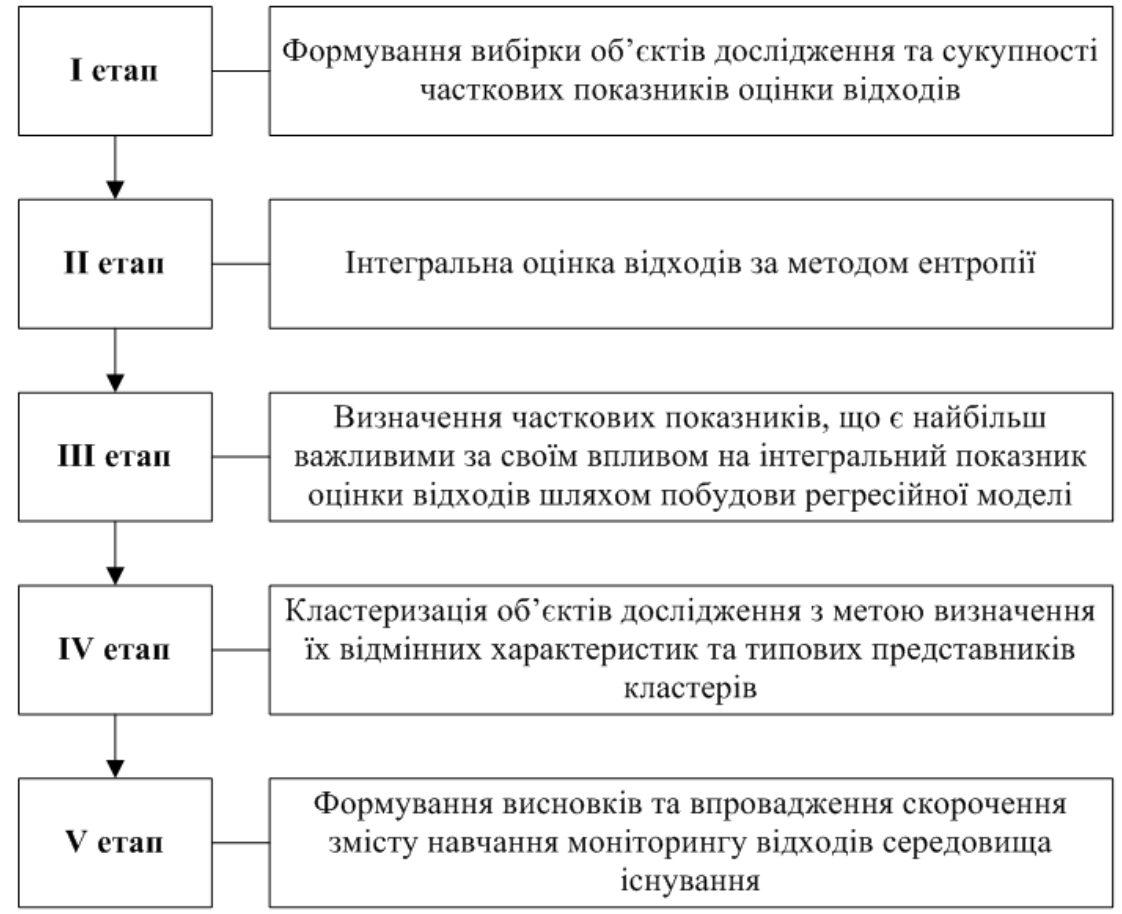

Рисунок 1 - Складові методу вертикальної редукції змісту навчання у вищій школі моніторингу відходів середовища існування

На першому етапі запропонованого методу здійснено формування об'єктів дослідження та вихідної сукупності часткових показників, що дозволяють оцінити стан відходів.

Об'єктами дослідження можуть виступати будь-які складові системи, що визначають середовище існування - країни, регіони, окремі міста та/або населені пункти, інші території, які мають специфічні характеристики відходів, що оцінюються в процесі моніторингу.
Відомо, що до сукупності часткових показників висуваються наступні вимоги [11]: здатність достатньо повно характеризувати об'єкт дослідження;

- бути доступними для вимірювання та/або в статистичних джерелах та дозволяти здійснювати оцінку в динаміці та за різними напрямами.

Відповідно до другого етапу формується інтегральний показник оцінки відходів за логічною схемою (рис. 2).

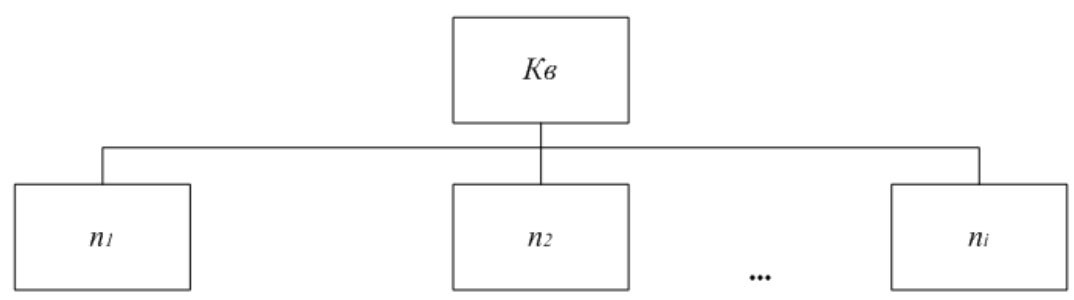

Рисунок 2 - Логіка формування комплексного показника оцінки відходів, 
ISSN 2074-8922 «Проблеми інженерно-педагогічної освіти», 2018, № 61

\section{उМICT ОСВІТИ}

де $K_{6}-$ інтегральний показник оцінки стану відходів;

$n_{l} \ldots n_{i}$ - часткові показники оцінки стану відходів.

Інтегральний показник оцінки відходів запропоновано розраховувати за методом ентропії.

Оскільки відходи $є$ складовою середовища існування як складної екологічної системи, можна стверджувати, що на їх стан та розвиток впливає багато чинників:

- виробництво, транспорт, житловокомунальне-господарство;

- сільськогосподарська діяльність;

- інші чинники.

Ці чинники мають свій вплив у комплексі та мають невпорядкований характер, тому системі притаманна ентропія, яку слід враховувати при проведенні інтегральної оцінки.

Враховуючи, що система стабільна тільки в тому випадку, коли стабільним $\epsilon$ кожен елемент (ознака) цієї системи, а якщо в системі якась ознака нестабільна, то ця нестабільність вплине на загальний стан всіх об'єктів у цілому [11], для оцінки відходів застосування методу ентропії є обгрунтованим. Тут мається на увазі міра хаосу та невпорядкованості елементів (ознак) будь-якої системи [11-12].

Інтегральне значення об'єкта $\epsilon$ інтегральною сумою наступного виду [11]:

$$
\begin{aligned}
& K_{\text {s }}=\sum_{J=1}^{n} H_{j} * b_{i j}, \\
& i=\overline{1, m}
\end{aligned}
$$
відходів;

де $K_{6}$ - інтегральний показник оцінки

$H_{j}$ - ентропія $j$-ї ознаки стану відходів;

$b_{i j}$ - кількісна оцінка $j$-ї ознаки для $i$ го об'єкта дослідження;

$m$ - кількість об'єктів;

$n$ - кількість ознак.

За формулою (1) розраховується інтегральний показник відходів.

Розрахунок здійснюється за такими етапами, представленими на рис. 3 .

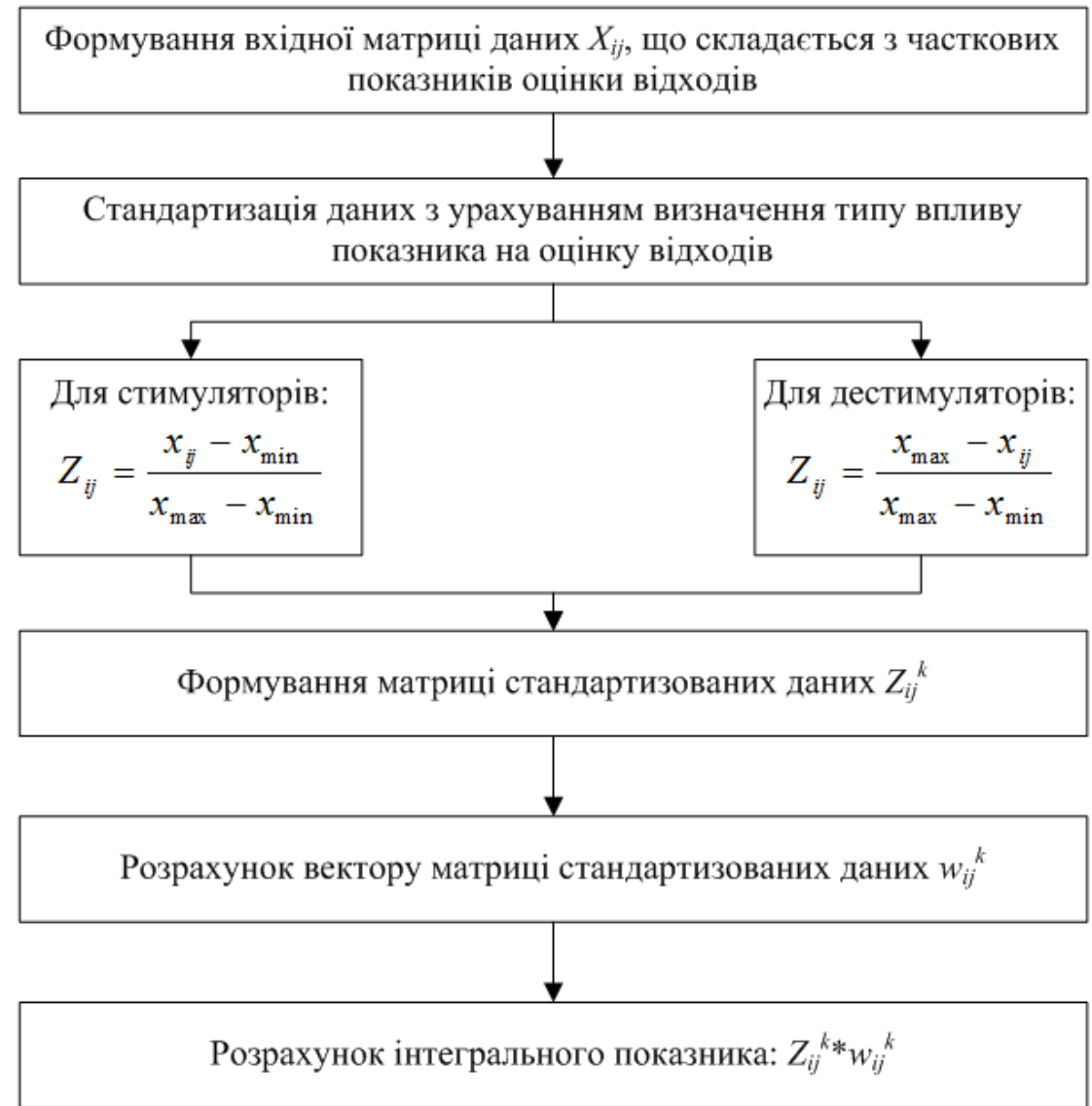

Рисунок 3 - Алгоритм розрахунку інтегрального показника оцінки відходів 
3 рис. 3 видно, що вектор матриці стандартизованих даних, $w_{i j}{ }^{k}$, враховує ентропію кожного стандартизованого часткового показника на k-му рівні, як передбачено формулою (1).

Згідно 3 методом (рис. 1) було визначено, що найбільш репрезентативними у межах наведеного дослідження об'єктами вимірювання є Україна та ії регіони, які мають диференційовані характеристики відходів, пов'язані 3 різними рівнями розвитку промисловості, стану житлово-комунального господарства, державною політикою поводження з відходами тощо.

У дослідженні, відповідно до статистичних даних [2], сформовано сукупність часткових показників оцінки стану відходів (табл. 1) та визначено тип впливу кожного показника на систему.

Стимуляторами $€$ ті часткові показники, зростання яких покращує стан системи. Дестимуляторами $\epsilon$ ті часткові показники, зростання яких погіршує стан системи.

Таблиия 1

Часткові показники оцінка сану довкілля за його складовими

\begin{tabular}{|c|c|c|}
\hline $\begin{array}{c}\text { Код } \\
\text { показника }\end{array}$ & Назва показника & $\begin{array}{c}\text { Тип впливу на } \\
\text { систему }\end{array}$ \\
\hline n.30 & Утворення відходів, тис. т & Дестимулятор \\
\hline n.31 & Утворення відходів I-III класів небезпеки, тис. т & Дестимулятор \\
\hline n.32 & $\begin{array}{l}\text { Утворення відходів у розрахунку на квадратний } \\
\text { кілометр території, т }\end{array}$ & Дестимулятор \\
\hline n.33 & Утворення відходів у розрахунку на одну особу, кг & Дестимулятор \\
\hline n.34 & Утилізація відходів, тис. т & Стимулятор \\
\hline n. 35 & Утилізація відходів I-III класів небезпеки, тис. т & Стимулятор \\
\hline n.36 & Спалювання відходів, тис. т & Дестимулятор \\
\hline n.37 & $\begin{array}{l}\text { Видалення відходів у спеціально відведені місця та } \\
\text { об'єкти, тис. т }\end{array}$ & Стимулятор \\
\hline n. 38 & $\begin{array}{l}\text { Видалення відходів І-ІІІ класів небезпеки у спеціально } \\
\text { відведені місця та об'єкти, тис. т }\end{array}$ & Стимулятор \\
\hline n.39 & Розміщення відходів на стихійних звалищах, тис. т & Дестимулятор \\
\hline n. 40 & $\begin{array}{l}\text { Загальний обсяг відходів, накопичених протягом } \\
\text { експлуатації, у місцях видалення відходів, тис. т }\end{array}$ & Дестимулятор \\
\hline n. 41 & $\begin{array}{l}\text { Загальний обсяг відходів, накопичених протягом } \\
\text { експлуатації, у м місцях видалення відходів } \\
\text { розрахунку на квадратний кілометр території, т }\end{array}$ & Дестимулятор \\
\hline n. 42 & $\begin{array}{l}\text { Загальний обсяг відходів, накопичених протягом } \\
\text { експлуатації, у м місцях видалення відходів } \\
\text { розрахунку на одну особу, кг }\end{array}$ & Дестимулятор \\
\hline
\end{tabular}

У табл. 2 наведено стандартизовані значення деяких часткових показників відходів у 2017 p. Стандартизацію проведено за формулами, наведеними на рис. 3.
Згідно із запропонованим методом, за кожним частковим показником у системі об'єктів вимірювання розраховано стандартне відхилення та обчислено вектор матриці, $w_{i j}{ }^{k}$. 
ISSN 2074-8922 «Проблеми інженерно-педагогічної освіти», 2018, № 61

ЗМІСТ ОСВІТИ

Таблиия 2

Стандартизовані значення деяких часткових показників стану відходів в Україні та їі регіонах, $2017 \mathrm{p}$.

\begin{tabular}{|c|c|c|c|c|c|c|c|c|}
\hline \multirow{2}{*}{$\begin{array}{c}\text { Об’єкти } \\
\text { вимірювання }\end{array}$} & \multicolumn{8}{|c|}{ Код часткового показника у системі вимірювання } \\
\hline & n30 & n31 & $\mathrm{n} 32$ & n33 & n34 & $\mathrm{n} 35$ & $\mathrm{n} 36$ & n37 \\
\hline $\begin{array}{l}\text { Україна (середнє } \\
\text { значення) }\end{array}$ & 0,9381 & 0,8547 & 0,9902 & 0,9116 & 0,0497 & 0,1020 & 0,7242 & 0,0663 \\
\hline Вінницька & 911 & 9965 & 9970 & 821 & $\overline{0042}$ & 0000 & 4924 & 0,0012 \\
\hline Волинська & 0,9977 & 0,9953 & 0,0000 & ,9925 & 0013 & 0,0008 & 0,8493 & 0,0044 \\
\hline Дніпропет & 0,0000 & 0,6887 & 0,8905 & 0,0000 & 1,0000 & 0,3192 & 0,7067 & 1,0000 \\
\hline & 9084 & 0,0000 & 9994 & 9311 & 0644 & 0000 & 9937 & 0,1468 \\
\hline & 9984 & 0,9947 & 0000 & 9959 & 010 & 0120 & 6969 & 0,0013 \\
\hline & 0000 & 9936 & 9770 & 00 & 0000 & 0008 & 9731 & 0,0013 \\
\hline $3 a n$ & 9796 & 8982 & 34 & 9624 & 23 &, 0770 & 5166 & 0,0181 \\
\hline Іван & 9927 & 0,9602 & 9959 & 9830 & 0078 & 0,0217 & $\overline{0000}$ & 0,0081 \\
\hline Київська & 0,9955 & 0,9590 & 0,8005 & 0,9922 & 0002 & 0,0369 & 0,9892 & 0,0104 \\
\hline Кіровогра & 0,8458 & 0,9643 & 0,9986 & 0,4806 & 0176 & 0,0120 & 0,7776 & 0,3378 \\
\hline Лугансь & 0,9981 & 0,9631 & 0,9868 & 0,9979 & 0,0011 & 0,0000 & 0,7336 & 0,0050 \\
\hline Львівсы & 0,9905 & 0,9854 & 0,9893 & 0,9888 & 0,0072 & 0,0024 & 0,6152 & 0,0100 \\
\hline Миколаї & 0,9911 & 0,9052 & 0,9989 & 0,9748 & 0,0007 & 0,0481 & 0,7112 & 0,0184 \\
\hline & 0,9977 & 0,9854 & 0,8411 & 0,9977 & 0,0001 & 0,0088 & 7767 & 0,0050 \\
\hline & & & & & & & 6493 & 0,0 \\
\hline & 0,9988 & 0,9971 & 0,9986 & 0,9966 & 0,0003 & 0,0008 & 0,2700 & 0,0014 \\
\hline & 9983 & 2253 & 9836 & 9948 & 0027 & 0,5613 & 8341 & 0,0032 \\
\hline Tep & 0,9929 & 0,9310 & 0,9942 & 0,9778 & 0,0012 & 0,0938 & 1,0000 & 0,0000 \\
\hline Xapr & 0,9933 & 0,6940 & 0,9999 & 0,9929 & 0,0014 & 0,0521 & 0,4027 & 0,0070 \\
\hline Xep & 0,9991 & 0,8438 & 0,9959 & 0,9968 & 0,0004 & 0,0393 & 0,8000 & 0,0003 \\
\hline Хмель & 0,9969 & 0,9807 & 0,9936 & 0,9922 & 0,0047 & 0,0000 & 0,9184 & 0,0019 \\
\hline Черкаська & 0,9954 & 0,9971 & 0,9958 & 0,9878 & 0,0091 & 0,0040 & 0,9247 & 0,0023 \\
\hline Черні1 & 0,9992 & 1,0000 & 0,9988 & 0,9964 & 0,0013 & 0,0000 & 0,8242 & 0,0017 \\
\hline Чернігівська & 0,9977 & 0,9965 & 1,0018 & 0,9923 & 0,0016 & 0,0016 & 0,9247 & 0,0025 \\
\hline$w_{i j}{ }^{k}$ & 0,0704 & 0,0889 & 0,0710 & 0,0786 & 0,0699 & 0,0791 & 0,0849 & 0,0729 \\
\hline
\end{tabular}

На рис. 4 наведено гістограму розподілу об'єктів дослідження за визначеним

інтегральним показником оцінки відходів у $2017 \mathrm{p}$.

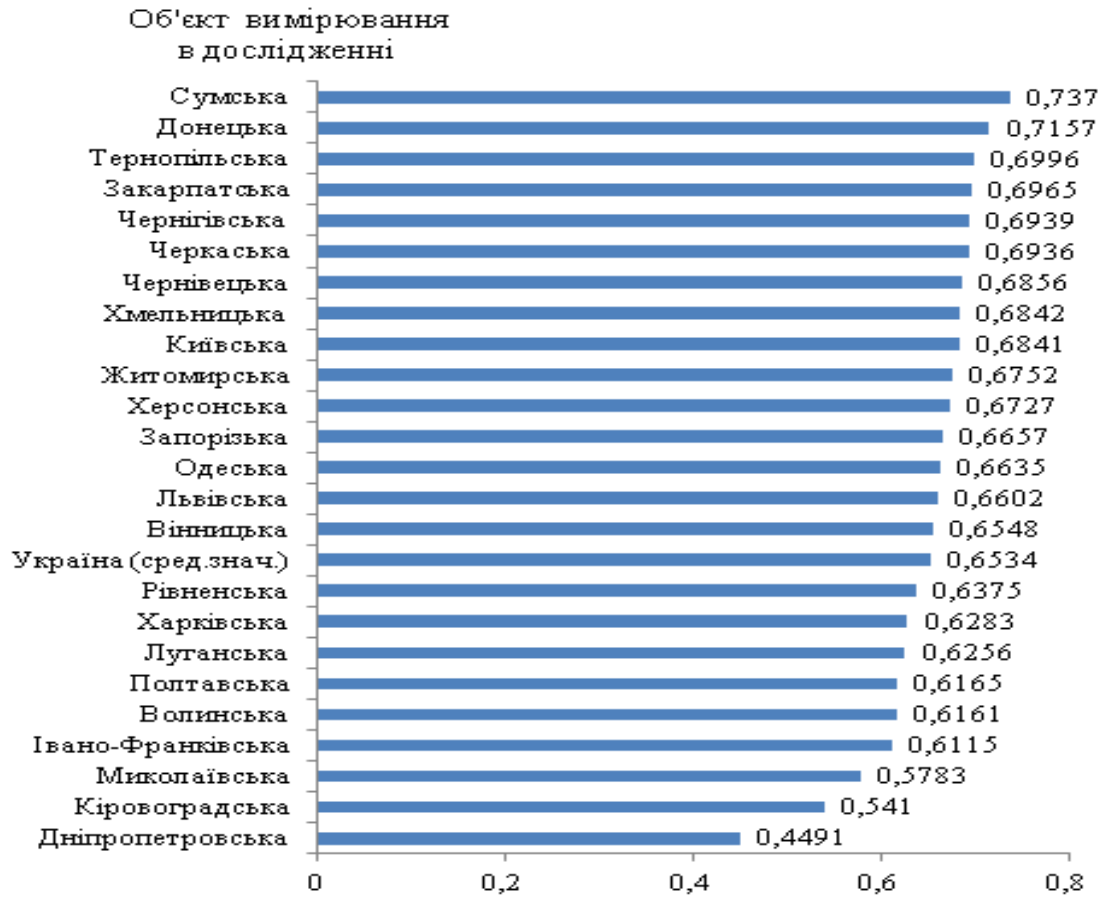


ISSN 2074-8922 «Проблеми інженерно-педагогічної освіти», 2018, № 61 उМICT ОСВITИ

Рисунок 4 - Розподілення об’єктів вимірювання за значеннями інтегрального показника «Відходи» оцінки стану середовища існування у 2017 р.

Наступний етап запропонованого методу передбачає побудову регресійної моделі для визначення часткових показників, що здійснюють найбільший вплив на інтегральний показник оцінки відходів 3 метою формування Із застосуванням ПП «STATISTICA 8.0» методом множинної регресії одержано наступні параметри рівняння оцінки впливу часткових показників на інтегральний показник оцінки відходів (табл. 3, рис. 5, 6).

навчальної програми.

Таблиия 3

Параметри регресійної моделі для визначення вагомості впливу часткових показників на зміну інтегрального показника відходів

\begin{tabular}{|c|c|c|c|c|}
\hline $\begin{array}{c}\text { Склад часткових } \\
\text { показників до } \\
\text { моделювання }\end{array}$ & \multicolumn{2}{|c|}{$\begin{array}{c}\text { Коефіцієнти } \beta \text { у регресійній } \\
\text { моделі }\end{array}$} & $\begin{array}{c}\text { Склад часткових } \\
\text { показників після } \\
\text { моделювання }\end{array}$ & $\begin{array}{l}\text { Достовірність } \\
\text { моделі }\left(\mathrm{R}^{2}\right)\end{array}$ \\
\hline \multirow{11}{*}{$\begin{array}{c}\text { n30, n31, n32, n33, } \\
\text { n34, n35, n36, n37, } \\
\text { n38, n39, n40, n41, } \\
\text { n42 }\end{array}$} & n33 & 0,2872 & \multirow{11}{*}{$\begin{array}{c}\mathrm{n} 30, \mathrm{n} 31, \mathrm{n} 32, \mathrm{n} 33, \\
\mathrm{n} 35, \mathrm{n} 36, \mathrm{n} 37, \mathrm{n} 38, \\
\mathrm{n} 39, \mathrm{n} 41, \mathrm{n} 34\end{array}$} & \multirow{11}{*}{0,9999} \\
\hline & n36 & 0,3378 & & \\
\hline & n39 & 0,4466 & & \\
\hline & $\mathrm{n} 32$ & 0,2364 & & \\
\hline & n38 & 0,2678 & & \\
\hline & $\mathrm{n} 30$ & 0,2352 & & \\
\hline & $\mathrm{n} 37$ & 0,1854 & & \\
\hline & n31 & 0,3741 & & \\
\hline & $\mathrm{n} 35$ & 0,3174 & & \\
\hline & $\mathrm{n} 41$ & 0,5554 & & \\
\hline & n34 & 0,1528 & & \\
\hline
\end{tabular}

\begin{tabular}{|c|c|c|c|c|c|c|}
\hline \multirow[b]{2}{*}{$N=25$} & \multicolumn{6}{|c|}{$\begin{array}{l}\text { Regression Summary for Dependent Variable: KB (Spreadsheet } \\
R=, 99999684 \mathrm{R} ?=, 99999368 \text { Adjusted R?= } 99998833 \\
F(11,13)=1869 E 2 p<0,0000 \text { Std. Error of estimate: }, 00021\end{array}$} \\
\hline & Beta & $\begin{array}{l}\text { Std.Err. } \\
\text { of Beta }\end{array}$ & $B$ & $\begin{array}{c}\text { Std. Err. } \\
\text { of } \mathrm{B}\end{array}$ & $t(13)$ & p-level \\
\hline Intercept & & & 0,039579 & 0,009982 & 3,9653 & 0,001614 \\
\hline n33 & $0,287255^{2}$ & 0,024968 & 0,077852 & 0,006767 & 11,5051 & 0,000000 \\
\hline n36 & 0,337738 & 0,000807 & 0,084740 & 0,000203 & 418,4481 & 0,000000 \\
\hline n39 & 0,446625 & 0,001007 & 0,097766 & 0,000221 & 443,3051 & 0,000000 \\
\hline n32 & 0,236423 & 0,000741 & 0,070939 & 0,000222 & 319,2226 & 0,000000 \\
\hline n38 & 0,267823 & 0,002580 & 0,073917 & 0,000712 & 103,8033 & 0,000000 \\
\hline n30 & 0,235199 & 0,061161 & 0,071145 & 0,018500 & 3,8456 & 0,002024 \\
\hline n37 & 0,185395 & 0,013397 & 0,054158 & 0,003914 & 13,8383 & 0,000000 \\
\hline n31 & 0,374081 & 0,003772 & 0,089587 & 0,000903 & 99,1860 & 0,000000 \\
\hline n35 & 0,317370 & 0,003669 & 0,085414 & 0,000987 & 86,4955 & 0,000000 \\
\hline n41 & 0,555467 & 0,030762 & 0,169190 & 0,009370 & 18,0567 & 0,000000 \\
\hline n34 & 0,152840 & 0,036308 & 0,046580 & 0,011065 & 4,2095 & 0,001021 \\
\hline
\end{tabular}

Рисунок 5 - Лістинг результатів регресійного аналізу оцінки впливу часткових показників на інтегральний показник оцінки відходів

3 табл. 3 та рис. 5 видно, що одержана модель є адекватною, про що свідчать високі значення коефіціснта детермінації, $\mathrm{R}^{2}$, скоректованого коефіцієнта детермінації, Adjusted $\mathrm{R}^{2}$, та низькі значення стандартної помилки оцінювання, Std. Error of estimate = 0,00021 .

Адекватність моделі також підтверджується картиною розподілу залишків моделі навколо прямої, як показано на рис. 6. 
ISSN 2074-8922 «Проблеми інженерно-педагогічної освіти», 2018, № 61 ЗМICТ ОСВIТИ

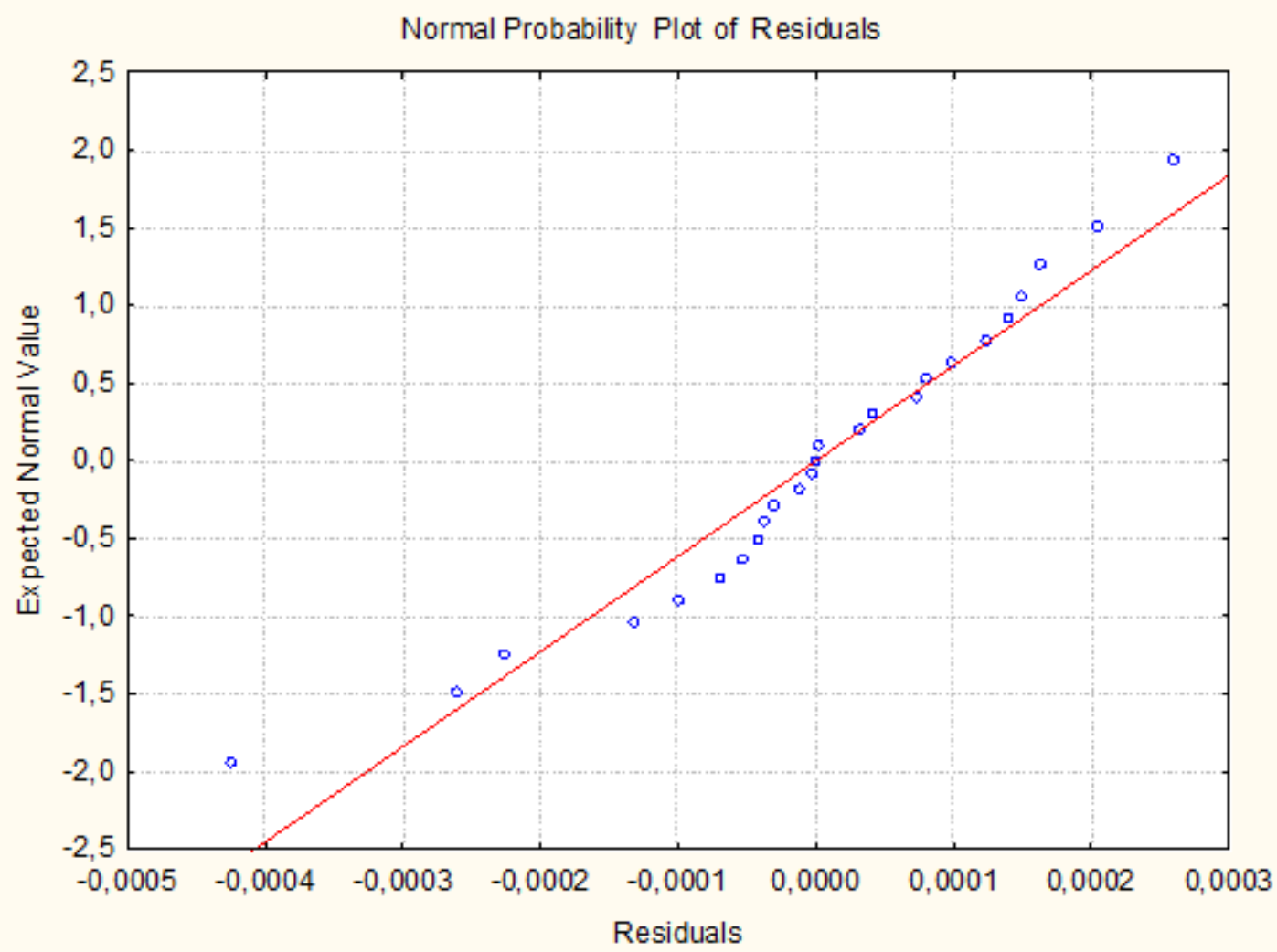

Рисунок 6 - Графік розподілу залишків регресійної моделі оцінки впливу часткових показників на інтегральний показник оцінки відходів

Четвертий етап запропонованого методу передбачає дослідження 3 метою визначення відмінних характеристик кластерів та типових представників кластерів для скорочення обсягу змісту навчання (табл. 4, рис. 7).

Таблиия 4

Результати кластеризації об'єктів дослідження за значеннями часткових показників моніторингу оцінки відходів у 2017 p.

\begin{tabular}{|c|c|c|c|c|c|}
\hline \multicolumn{2}{|c|}{ Кластер 1} & \multicolumn{2}{|c|}{ Кластер 2} & \multicolumn{2}{|c|}{ Кластер 3} \\
\hline \multicolumn{2}{|l|}{1} & \multicolumn{2}{|c|}{2} & \multicolumn{2}{|c|}{3} \\
\hline Склад кластеру & $\begin{array}{c}\text { Евклідова } \\
\text { відстань між } \\
\text { об'єктами }\end{array}$ & Склад кластеру & $\begin{array}{c}\text { Евклідова } \\
\text { відстань між } \\
\text { об’єктами }\end{array}$ & $\begin{array}{c}\text { Склад } \\
\text { кластеру }\end{array}$ & $\begin{array}{c}\text { Евклідова } \\
\text { відстань між } \\
\text { об'єктами }\end{array}$ \\
\hline Дніпропетровська & 0 & Вінницька & 0,074426 & Донецька & 0,104330 \\
\hline & & Волинська & 0,264416 & Сумська & 0,104330 \\
\hline Склад кластеру & $\begin{array}{c}\text { Евклідова } \\
\text { відстань між } \\
\text { об'єктами }\end{array}$ & Склад кластеру & $\begin{array}{c}\text { Евклідова } \\
\text { відстань між } \\
\text { об'єктами }\end{array}$ & $\begin{array}{c}\text { Склад } \\
\text { кластеру }\end{array}$ & $\begin{array}{c}\text { Евклідова } \\
\text { відстань між } \\
\text { об'єктами }\end{array}$ \\
\hline Дніпропетровська & 0 & Вінницька & 0,074426 & Донецька & 0,104330 \\
\hline & & Волинська & 0,264416 & Сумська & 0,104330 \\
\hline & & Житомирська & 0,045726 & & \\
\hline & & Закарпатська & 0,085960 & & \\
\hline & & Запорізька & 0,084056 & & \\
\hline & & $\begin{array}{l}\text { Івано- } \\
\text { Франківська }\end{array}$ & 0,200275 & & \\
\hline & & Київська & 0,093944 & & \\
\hline & & Кіровоградська & 0,295863 & & \\
\hline
\end{tabular}


ISSN 2074-8922 «Проблеми інженерно-педагогічної освіти», 2018, № 61

\section{3МICT ОСВITИ}

Продовження таблииі 4

\begin{tabular}{|l|l|l|l|l|l|}
\hline \multicolumn{2}{|c|}{} & \multicolumn{2}{|c|}{2} & \multicolumn{2}{c|}{3} \\
\hline & & Луганська & 0,107746 & & \\
\hline & & Львівська & 0,050628 & & \\
\hline & & Миколаївська & 0,224765 & & \\
\hline & Одеська & 0,040810 & & \\
\hline & & Полтавська & 0,146228 & & \\
\hline & Рівненська & 0,129654 & & \\
\hline & & Тернопільська & 0,092516 & & \\
\hline & Харківська & 0,115287 & & \\
\hline & Херсонська & 0,055108 & & \\
\hline & Хмельницька & 0,066264 & & \\
\hline & & Черкаська & 0,075282 & & \\
\hline & & Чернівецька & 0,056769 & & \\
\hline & & Чернігівська & 0,075863 & & \\
\hline
\end{tabular}

Кластерний аналіз проведено методом $\mathrm{k}$ середніх за правилом повних зв'язків у ПП «STATISTICA 8.0» 3 метою створення трьох найбільш розбіжних кластерів об'єктів дослідження, які характеризують показник відходів у досліджуваній сукупності об'єктів.

Отже, до кластеру 1 потрапив Дніпропетровський регіон. Результат підтверджується й найбільш низьким значенням інтегрального показника відходів у цьому регіоні (25-е місце у рейтингу).

До кластеру 2 потрапив 21 регіон. В межах редукції змісту навчання моніторингу відходів середовища існування запропоновано визначення типових представників кластеру за найменшими значеннями евклідової відстані від об'єкту до центру кластеру.

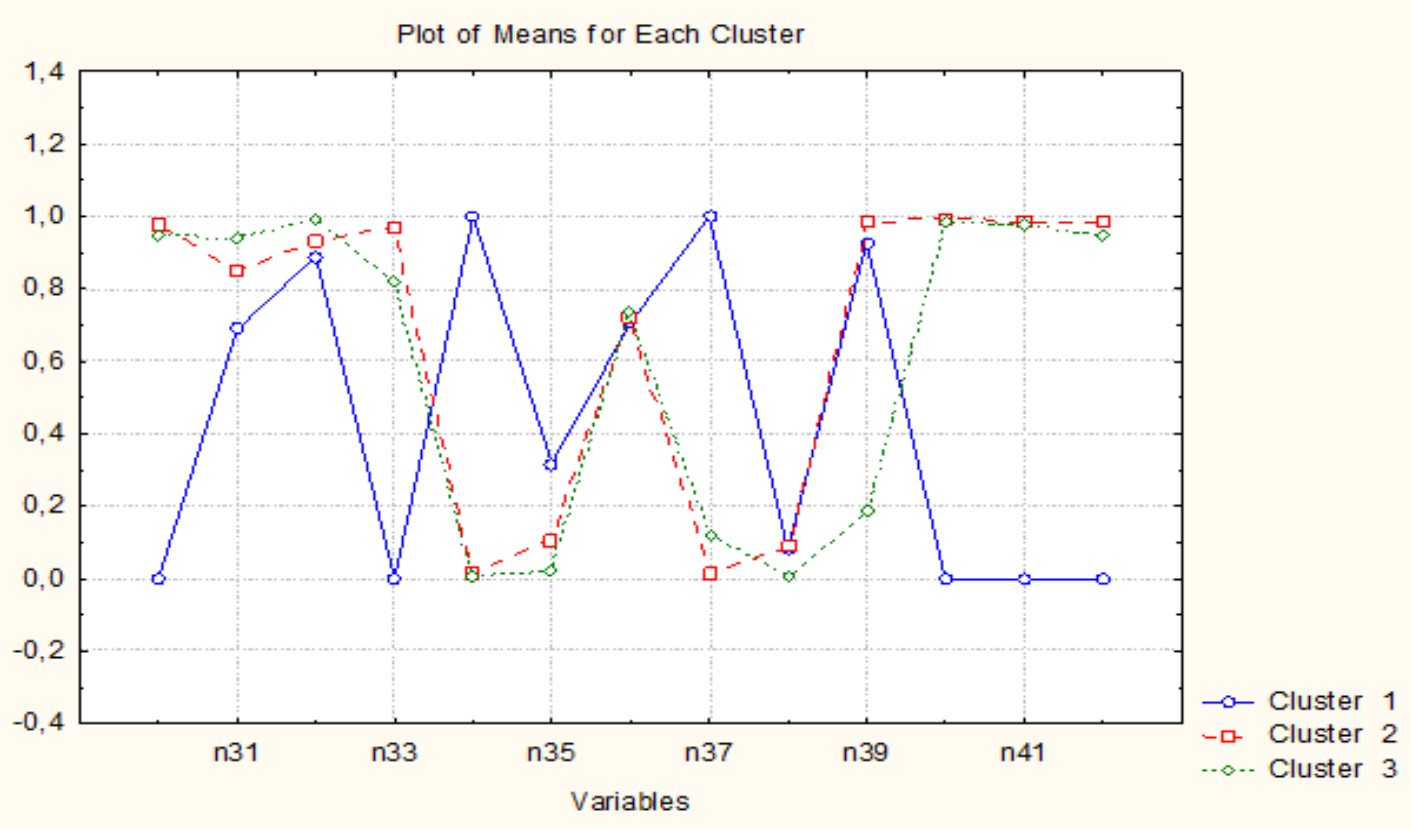

Рисунок

7 - Графік розподілу значень для кластерів об’єктів дослідження за частковими показниками оцінки відходів
Типовими представниками кластеру 2 є Одеський та Житомирський регіони. Таким чином, вибірка об'єктів може бути скорочена за рахунок переходу до представників кластеру 2 починаючи 3 представника, що має найменше значення евклідової відстані, тобто починаючи з найбільш типового представника.

До кластеру 3 потрапили Донецький та Сумський регіони, які мають однакові евклідові відстані до центру кластеру. Результат підтверджується лідируючими позиціями цих регіонів у рейтингу інтегрального показника оцінки стану відходів у 2017 p. (1-е місце Сумський регіон та 2-е місце Донецький). 
Як видно 3 рис. 7, середні значення досліджуваних показників у рамках трьох визначених кластерів відрізняються між собою, а відстані між центрами кластерів достатньо значні.

Відповідно до п’ятого етапу здійснення методу (рис. 1), здійснено формування висновків та впровадження скорочення змісту навчання моніторингу відходів існування.

Отже, в результаті впровадження методу на етапі застосування методу регресії отримано наступні показники, що чинять найбільший вплив, із відповідними коефіцієнтами впливу на інтегральний показник «Відходи»:

- утворення відходів - 0,2352;

- утворення відходів I-III класів небезпеки - 0,3741;

- утворення відходів у розрахунку на квадратний кілометр території - 0,2364;

- утворення відходів у розрахунку на одну особу - 0,2872;

- утилізація відходів - 0,1528;

- утилізація відходів I-III класів небезпеки - 0,3174;

- спалювання відходів - 0,3378;

- видалення відходів у спеціально відведені місця та об'єкти - 0,1854;

- видалення відходів І-ІІІ класів небезпеки у спеціально відведені місця та об'єкти - 0,2678;

- розміщено відходів на стихійних звалищах - 0,4466;

- загальний обсяг відходів, накопичених протягом експлуатації, у місцях видалення відходів у розрахунку на квадратний кілометр території-0,5554.

Інші показники не чинять статистично значущого впливу на інтегральний показник i можуть бути проаналізовані у навчальному процесі після показників, що чинять такий вплив, у довільному порядку.

На підставі отриманих результатів викладач може формувати програму навчання, а студенти, можуть аналізувати показники відходів середовища існування в процесі навчання або в процесі своєї професійної діяльності у послідовності за ступенем впливу показників на інтегральний показник відходів середовища існування.

Формування вибірки об'єктів вимірювання, стандартизацію одиниць вимірювання, застосування методу ентропії та визначення інтегрального показника та застосування методу регресії ті, хто навчаються, можуть проводити самостійно під наглядом викладача для засвоєння навичок визначення головного 3 масиву даних в процесі професійної діяльності. Ці операції також можуть виконуватись викладачем для охоплення найголовніших аспектів в процесі навчання в умовах обмеженого часу.

Кластерний аналіз призвів до поєднання у сукупність та визначення характерних представників за одним кластером, що дозволяє в процесі навчальної діяльності аналізувати усіх представників кластеру послідовно починаючи, 3 найбільш характерного представника кластеру. Крім того, формування трьох кластерів дає можливість оцінювати їх у системі «погано нормально - добре».

Застосування методу призводить до зменшення часу на проведення вимірювань, розрахунків, аналізу за отримання наближеного результату при статистично малих похибках, що дозволяє максимізувати інформацію щодо отриманих результатів в умовах обмеженого часу на навчання моніторингу відходів середовища існування, а також в умовах обмеженого часу його безпосереднього здійснення у майбутній професійній діяльності.

Висновки. Отже, розроблено метод вертикальної редукції змісту навчання у вищій школі моніторингу відходів середовища існування. Метод відповідає характерним ознакам дидактичної редукції - допомагає надати змісту певної форми і узгодити його із нормованим часом, а також забезпечує формування обсягу достатньої інформації для оволодіння конкретним аспектом моніторингу відходів середовища існування. При цьому достатність змісту обгрунтовано, перевірено та підтверджено методами математичної статистики, що дозволило трансформувати якісні змінні «достатньо» та «важливо» у кількісні змінні.

Перспективи подальших досліджень. Додаткових досліджень потребує імплементація розробленого методу у процесі навчання моніторингу атмосферного повітря, використання водних ресурсів, внесення добрив і застосування пестицидів, охорони та використання лісових ресурсів, оцінки витрат на охорону навколишнього природного середовища. 


\section{Список використаних джерел}

1. Кіпоренко Г. С. Моніторинг середовища існування : навч. посіб. для студентів вищ. навч. закладів інж.-пед. спец. / Г. С. Кіпоренко. - Харків : УІПА, 2013. - $404 \mathrm{c}$.

2. Статистичний збірник Довкілля України за 2017 рік / За редакцією О. М. Прокопенко. - Київ : Державна служба статистики України, 2018. - 225 c.

3. Pat. TW201834474 (A), IPC G06F17/30; H04L29/02; H04L29/06; H04W4/02. Monitoring system / Huang Szu-Wei, Hsu Che-Wei ; applicant Anasystem Inc. - Appl. № TW20170107568 ; filed 08.03.2017 ; pub. date 16.09.2018.

4. Pat. CN207233252 (U), IPC G09B19/00. Waste classification teaching aid / Zhou Qungang ; applicant Hangzhou Lian Env Engineering Co Ltd. Appl. № CN201621454997U ; filed 28.12.2016 ; pub. date 03.10.2017.

5. Lehner M. Didaktische Reduktion / M. Lehner. - Bern: Haupt, 2012. - $211 \mathrm{~s}$.

6. Zeimet R. Approaches to Teaching Biometry and Epidemiology at Two Veterinary Schools in Germany [Electronic resource] / R. Zeimet, L. Kreienbrock, M. G. Doherr // Journal of Veterinary Medical Education. - 2016. - Vol. 43(2). - viewed 12 October 2018, Acces mode : http://jvme.utpjournals.press/doi/abs/10.3138/jvme.091 5-152R1.

7. Grüner G. Die didaktische Reduktion als Kernstück der Didaktik / G. Grüner // Die Deutsche Schule. - 1967. - Nr. 59. - S. 414-430.

8. Costa G. GraphsJ 3: A modern didactic application for graph algorithms / G. Costa, C. D'Ambrosio, S. Martello // Journal of Computer Science. - 2014. - Vol. 10 (7). - P. 1115-1119.

9. Shmatkov D. The use of causal maps as interdisciplinary didactic reduction method / D. Shmatkov // Advanced Education. - 2016. - Iss. 6. - P. 16-21.

10. Buschfeld D. Draußen vom Lernfeld komm' ich her. Plädoyer für einen alltäglichen Umgang mit Lernsituationen / D. Buschfeld // Berufs- und Wirtschaftspädagogik - 2003. - Ausgabe 4. - S. 1-21.

11. Статистический анализ многомерных объектов произвольной природы / В. И. Васильев [и др.]. - М. : Издательство ИКАР, 2004. - 382 с.

12. Wilson A. Entropy in Urban and Regional Modelling (Routledge Revivals) / A. Wilson. Routledge, 2013. - 178 p.

\section{References}

1. Kiporenko, HS 2013, Monitorynh seredovyshcha isnuvannia, [Livestock monitoring] Ukrainska inzhenerno-pedahohichna akademiia, Kharkiv.

2. Prokopenko, OM (ed.) 2018, Statystychnyi zbirnyk Dovkillia Ukrainy za 2017 rik, [Statistical collection Environment of Ukraine for 2017] Derzhavna sluzhba statystyky Ukrainy, Kyiv.

3. Szu-Wei, H \& Che-Wei, H 2018, Monitoring system, Patent TW201834474 (A), IPC G06F17/30; H04L29/02; H04L29/06; H04W4/02, Appl. № TW20170107568 ; filed 08.03.2017 ; pub. date 16.09.2018

4. Qungang, Z 2017, Waste classification teaching aid, Patent CN207233252 (U), IPC G09B19/00, Appl. № CN201621454997U ; filed 28.12.2016 ; pub. date 03.10.2017.

5. Lehner, M 2012, Didaktische Reduktion, Haupt, Bern..

6. Zeimet, R, Kreienbrock, L, \& Doherr, MG 2016, 'Approaches to Teaching Biometry and Epidemiology at Two Veterinary Schools in Germany', Journal of veterinary medical education, vol. 43, iss. 4, pp. 332-343, viewed 12 October 2018, $<$ http://jvme.utpjournals.press/doi/abs/10.3138/jvme.09 15-152R1>.

7. Grüner, G 1967, 'Die didaktische Reduktion als Kernstück der Didaktik', Die Deutsche Schule, no. 59(7/8), pp. 414-430.

8. Costa, G \& Martello, S 2014, 'Graphsj 3: A modern didactic application for graph algorithms', Journal of Computer Science, vol. 10 (7), pp. 11151119.

9. Shmatkov, D 2016, 'The use of causal maps as interdisciplinary didactic reduction method', Advanced Education, iss. 6., pp. 16-21.

10. Buschfeld, D 2003, 'Draußen vom Lernfeld komm' ich her. Plädoyer für einen alltäglichen Umgang mit Lernsituationen', Berufs- und Wirtschaftspädagogik, iss 4, pp. 1-21.

11. Vasilev, VI et al. 2004, Statisticheskij analiz mnogomernyh obektov proizvolnoj prirody, [Statistical analysis of multidimensional objects of arbitrary nature] Izdatelstvo IKAR, Moskva.

12. Wilson, A 2013, Entropy in Urban and Regional Modelling (Routledge Revivals), Routledge.

Стаття надійила до редакиї̈ 20.10.2018p. 